\title{
Differences in blood pressure before and after consuming cucumber juice (Cucumis sativus) in women aged $30-40$ years
}

\author{
Martin Franklin*, Edeh Roletta Haroen*, Sri Tjahajawati*
}

*Department of Oral Biology Faculty of Dentistry Universitas Padjadjaran

\begin{abstract}
Introduction: Cucumber contains pottasium that can decrease blood pressure. This study was implemented to obtain data about the difference in blood pressure before and after consuming cucumber essence (Cucumis sativus) at women aged 30-40 years. Aim of this research is to analyzed difference s of blood pressure between before and after consuming cucumber essence (Cucumis sativus) at women aged 30-40 years. Methods: This study was a quasi-experimental with pair measurement statistic data test. Total samples of this study were 30 women at RW 02, Sukawarna district, Sukajadi, house of the village-head. Results: the average of systole before consume cucumber essence was $119,29 \mathrm{mmHg}$ and after to be $115,09 \mathrm{mmHg}$. The average of diastole before consume cucumber essence was $80,91 \mathrm{mmHg}$ and after to be $78,16 \mathrm{mmHg}$. Statsitic analysis showed if $\mathrm{a}=0,05(\mathrm{t} 0,975)$ value of tcalc both systolic and diastolic blood pressure > ttable so that $\mathrm{HO}$ rejected and $\mathrm{H} 1$ accepted. Conclusion: this study showed a difference in blood pressure between before and after consuming cucumber essence (Cucumis sativus) at women aged $30-40$ years.
\end{abstract}

Keywords: Cucumber essence, blood pressure, differences in blood pressure.

\section{INTRODUCTION}

To obtain a healthy body is not as difficult as imagined by society so far. Today, society's awareness to maintain health is better than it was a few years before. There are various ways society practice to keep their body healthy. However, sometimes society still want everything that is practical. Society with high economic ability, tend to choose a variety of supplements.

The important thing to note for the body to stay healthy is to consume a healthy and balanced diet, set the diet, and exercise regularly. Food consumed daily af-fects the health of the body. Today there are many food products that offer various health benefits for the body. A healthy body gives every individual the ability to do all activities well. This situation is everyone's dream. Health is a perfect state of physical, mental and social well-being, not limited to free from disease or weakness only. World Health Organization, giving a normal blood pressure limit of $140 / 90$ $\mathrm{mmHg}$, and blood pres-sure equal to or above $160 / 95 \mathrm{mmHg}$ expressed as hypertension. ${ }^{1}$

Blood pressure can be controlled through drugs. The monetary crisis that struck Indonesia and con-tinued into a prolonged economic crisis has re-sulted in drastic increases in drug prices because more than $90 \%$ of its components are imported. Expensive medicines are a problem for 
Indonesian society today. ${ }^{2}$ As a result of the price of expensive medicines, many people are turning to using traditional medicines with rela-tively more affordable prices. principle there are two kinds of therapies that can be done to lower blood pressure, namely pharmacological therapy using drugs and non-pharmacological therapy that is by modifica-tion of everyday life patterns and back to natural products or back to nature. ${ }^{3}$ Traditional medicines generally come from nature.

Drugs derived from natural materials are believed to be able to cope with various diseases and have a relatively high level of security. At this time the tendency to use treatment with natural ingredients began to be applied in Indonesia. ${ }^{1}$ Cucumber is one of the plants used in the treatment of various diseases. Cucumbers are often used as a health medicine. Asians have a habit of drinking cucumber juice in summer, perhaps because the cucumber has a refreshing effect.

Currently, the utilization of cucumber as food has been done by many people both in the villages and in the cities. Cucumber has a few of benefits that are very beneficial to the body. The biggest benefit of cu-cumber is its ability to lower high blood pressure, because cucumbers contain potassium in addition to magnesium and phosphorus. Potassium is used in the body to control blood pressure, high blood therapy, and clean carbon dioxide in the blood.

Moreover, cucumbers are also known to have a di-uretic effect, so as to reduce the levels of salt in the blood through the urine. Reduced levels of salt that is absorbing or holding water will reduce the volume of blood so as to lighten the heart's work in pumping blood, and finally blood pressure will decrease. ${ }^{2}$ Likewise, magnesium can help lower blood pressure. In women, blood pressure increas-es faster than men. This situation is seen during menopause, women's blood pressure becomes slightly higher than the male blood pressure. Also, women tend to stress faster than men.

As a dentist it is important to perform a blood pressure examination on a patient before performing dental treatment. ${ }^{3}$ High blood pressure and low blood pressure is very vulnerable to human health and tend to be dangerous, especially during dental treatment such as tooth extraction. Therefore, to determine the patient's blood pres- sure before doing the treatment, blood pressure examinations are done. In this case the dentist usually refers to the doctor to be given a medication to lower his blood pressure. In general, normal systolic pressure in young adults in a resting state in a sitting position or lying is approximately 120 $\mathrm{mmHg}$ and diastolic pressure of approximately 80 $\mathrm{mmHg} .{ }^{4}$ Blood pressure examination is a supporting ex-amination as a consideration in determining the diagnosis and health indicators. ${ }^{5}$

Based on the theoretical information that has been described in the background of research and encouraged by people who are curious about the cucumber, the authors feel interested to conduct research on the difference in blood pressure be-fore the after consuming cucumber juice in wom-en aged 30-40 years in the Sukawarna sub-district Sukajadi city of Bandung. The author hopes through this research, data about cucumber can be found and in the end cucumber can be used as a healthy food choice for the community. Aim of this research is to analyzed difference $s$ of blood pressure between before and after consuming cucumber essence (Cucumis sativus) at women aged $30-40$ years.

\section{METHODS}

This type of research is quasi experimental by measuring systolic and diastolic blood pressure before taking cucumis sativa (cucumis sativa) in women aged 30-40 years. Blood pressure data prior and after consuming cucumber extract obtained was tabulated and analyzed by statistical tests. The statistical test used is $t$ student statistic for paired test so that the result of difference of blood pressure value before with after consuming cucumis sativa (cucumis sativa) in woman aged 30-40 years.

\section{RESULTS}

and after consuming Cucumis sativus (Cucumis sativus) in women aged 30-40 years. To determine the difference in mean blood pres-sure before taking Cucumis sativus (Cucumis sati-vus) in women aged 30-40 years. The mean value of naracoba blood pressure before taking cucum-is sativus (Cucumis sativus) in women aged 30-40 years is presented in Table 4.1, while statistical 
Table 1. Average Blood Pressure Before And After Consuming Cucumber Extract (Cucumis sativus) In Women Age 30-40 Years

\begin{tabular}{cccccccc}
\hline \multicolumn{3}{c}{ Systole $(\mathrm{mmHg})$} & \multicolumn{3}{c}{ Diastole $(\mathrm{mmHg})$} \\
\hline \multicolumn{2}{c}{ Before } & \multicolumn{2}{c}{ After } & \multicolumn{2}{c}{ Before } & \multicolumn{2}{c}{ After } \\
\hline Average & Deviation & Average & Deviation & Average & Deviation & Average & Deviation \\
\hline 119.29 .00 & 29.94 & 115.09 .00 & 0,931944444 & 80.91 & 0,6666667 & 78.16 .00 & 0,6708333 \\
\hline
\end{tabular}

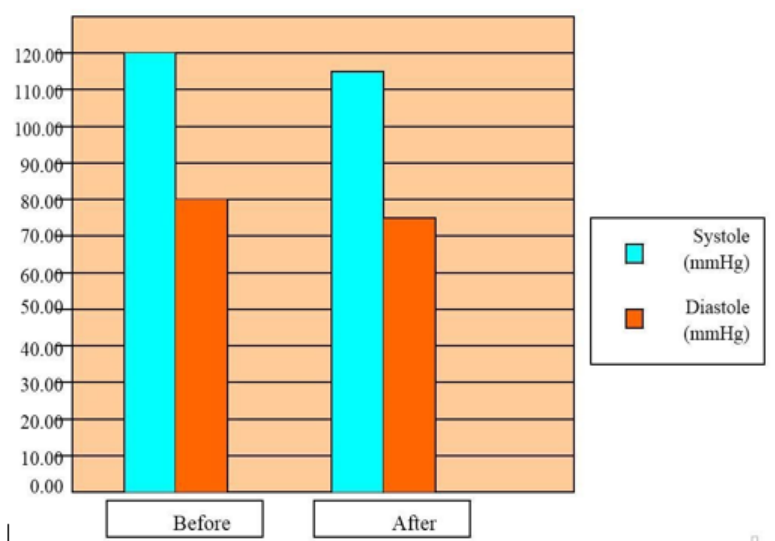

Picture 1. Average Blood Pressure Before And After Consuming Cucumber Extract (Cucumis sativus) In Women Age 30-40 Years

analysis is presented in Table 4.2. Table 1. shows an average systolic pressure before consuming cucumber juice of $119.29 \mathrm{mmHg}$ with standard deviation of 21.94 and after consuming cucumber juice of $115.09 \mathrm{mmHg}$

Tabel 2. Differences in Mean Blood Pressure Value Before and After Consuming Cucumber Juiceln Women Ages 30-40

\begin{tabular}{ccccc}
\hline No & $\begin{array}{c}\text { Calcula- } \\
\text { tion Blood } \\
\text { pressure }\end{array}$ & $\begin{array}{c}\text { Total } \\
\text { Difference }\end{array}$ & $\begin{array}{c}\text { Devi- } \\
\text { ation }\end{array}$ & t total \\
\hline 01.00 & Systole & 04.02 & 21.08 & 0,19375 \\
02.00 & Diastole & 0,136111111 & 15.59 & 0,142361111 \\
\hline
\end{tabular}

with standard deviation of $21.82 \mathrm{mmHg}$. The average diastolic pressure before consuming cucumber extract was $80,91 \mathrm{mmHg}$ with standard deviation 15,60 and after consuming cucumber juice $78,16 \mathrm{mmHg}$ with standard deviation 15,66 $\mathrm{mmHg}$. Table 2 showed difference of mean value of systolic pressure before and after consuming cucumber juice amounts to $4,20 \mathrm{mmHg}$ with standard deviation 21,80 and based on statistical analysis got $t$ count equals to 3,99 difference of mean value of diastolic pressure before and after consuming cucumber extract equal to $2.76 \mathrm{mmHg}$ with standard deviation of 15.59 and based on statistical analysis t obtained by 2.85 .

\section{DISCUSSION}

Based on the results of research that has been done on blood pressure before and after consuming Cucumis sativus in women aged 30-40 years, the obtained t count is 3.99 for systolic blood pressure and $\mathrm{t}$ count is $\mathbf{2 . 8 5}$ for diastolic blood pressure.

This result means it is absolute that the form is larger than $t$ table that is 2.04 . This means that there is a difference in blood pressure before taking Cucumis sativus (Cucumis sativus) in women aged $30-40$ years. Blood pressure after consuming cucumber juice decreased. The decrease in systolic blood pressure after consuming cucumber juice from an average of $119.29 \mathrm{mmHg}$ to 115.09 $\mathrm{mmHg}$ and a drop in diastolic pressure from an average of $80.91 \mathrm{mmHg}$ to $78.16 \mathrm{mmHg}$.

The results suggest a decrease in blood pressure after consuming cucumber juice (Cucumis sativus) in women aged $30-40$ years. This is in accordance with the theory presented earlier. The drop in blood pressure is caused by the diuretic effect, as well as the potassium content found in the cu-cumber.

The diuretic effect in the cucumber causes the salt content in the blood to decrease. Reduced levels of salt that is absorbing or holding water will reduce the volume of blood so as to lighten the heart's work in pumping blood, and eventually the blood pressure will decrease. Potassium is a mineral that functions to regulate body fluid balance. Consumption of potassium in large quantities will increase its concentration in the intracellular fluid, thus draw-ing fluid from the extracellular part and lowering blood pressure. ${ }^{2}$

As a dentist it is important to perform blood pres-sure examination on patients before performing any action or dental treatment. Patients who have normal blood pressure will not cause complica-tions if there will be an action or dental treatment such as anesthesia and extraction. 


\section{CONCLUSION}

There is a difference in blood pressure before and after con-suming Cucumis sativus (Cucumis sativus) in wom-en aged 30-40 years.

\section{REFERENCES}

1. WHO. Health Authorities Act. 9th Ed. WB: Saunders. 1960.

2. Maheswari, H. 2002. Pemanfaatan obat alami. www.litbang.depkes.go.id (diakses 13 September 2009).

3. Ainur, R Hartati. Petunjuk Teknis Perkandangan Sapi Potong. Pusat Penelitian dan Pengembangan Peternakan. Lokal Penelitian
Sapi Potong Grati Pasuruan. 2007.

4. Astawan, M. 2002. Menggali potensi tempe sebagai penurun tekanan darah. www.web. ipb. ac.id (diakses 13 September 2009)

5. Vyati, E.I. 2006. Mengenal tanda-tanda sepsis akibat infeksi odontogenik. http : www. messen-ger.com (diakses 13 September 2009)

6. Ganong, W.F. 2002. Buku Ajar Fisiologi Kedok-teran. Diterjemahkan dari Review of Medical Phsiology. Alih bahasa : M. Djauhari Widjajakusumah. Jakarta : EGC. 557-587

7. Litbang Depkes RI. 2007. Pedoman pengukuran dan pemeriksaan

8. Obikoya. Potassium is a mineral that functions to regulate body fluid balance. $1^{\text {st }} \mathrm{Ed}$. Blood Pressure Association: UK. 2005. 